\title{
Spatial Distribution of Some Macro and Micro Nutrients in Relation to Land Evaluation Classes in Undulating Bushland Valleys of Melbourne Area
}

\author{
Haleema A Abdulrahman ${ }^{1}$, Kusay Wheib ${ }^{2}$, Deli Chen ${ }^{3}$ \\ ${ }^{1,2}$ University of Baghdad \\ ${ }^{3}$ University of Melbourne
}

\begin{abstract}
Fourteen locations for soil samples were selected from bushland valleys of Melbourne area to represent an undulating landscape where soils positioned on different settings of landforms to study the geo-spatial distribution of some available macro and micro nutrients in soil and their relation to some topographical features. Measured nutrients were available nitrogen $N$, carbon $C$, phosphorous $P$, potassium $\mathrm{K}$, calcium $\mathrm{Ca}$, magnesium $\mathrm{Mg}$, sodium $\mathrm{Na}$, manganese $\mathrm{Mn}$, iron $\mathrm{Fe}$, sulfur $\mathrm{S}$, copper Cu, barium $\mathrm{B}$, aluminum AL. these nutrients showed different geo-spatial distribution due to soil properties and topographical features. High amounts of Aluminum and iron were available in soil due to the mild acidic reaction in soil also, calcium occurred in some noticeable values where that was related to the origin of the parent materials in the area of study. $\mathrm{pH}$ and Organic matter were the main two soil properties that influenced the availability of macro and micro nutrients. The hierarchical analysis showed three grouping of soil variability, The first group included $\mathrm{N}, \mathrm{Cu}, \mathrm{Na}, \mathrm{P}, \mathrm{C}, \mathrm{B}, \mathrm{S}, \mathrm{K}$, and $\mathrm{Mn}$, and the second group was $\mathrm{Fe}, \mathrm{Mn}, \mathrm{K}$, and $\mathrm{S}$. Mg and Al were classified together and $C a$ was a whole one group. Elevation and flow accumulation were the most topographical features influencing the distribution of nutrients in soil. Another regression analysis was done to find the relationship between land evaluation classes and the spatial distribution of nutrients in an attempt to see the dominance of nutrients in relation to land evaluation class.
\end{abstract}

Keywords: macronutrients, micronutrients, land evaluation, variability, GIS

\section{Introduction}

Zonneveld 1983 has reported that evaluation of natural resources based on natural resources surveys is necessary to obtain the optimal land use to stop and prevent deterioration. Also FAO 1984 stated that the basis of land evaluation is a process of comparison between lands and their uses where decisions should be made for the use of lands that they are always part of human society. And to reduce human influence on natural resources and identify a suitable land use, there are some essential land evaluation processes to be carried out scientifically (AbdelRahman et al 2016).

Land evaluation is only part of the process of land use planning (Oldmen et al. 1991, FAO 1979) where the process of land evaluation plays a major part in formulation of proposals, recognition of delineation of land use types present in the area of study, and the comparison and evaluation process of each type of land for different uses. Rossiter 1994 described evaluation unit as they are always map units of soil resources inventories, and they are usually of soil surveys suitable for farm plans. Therefore some evaluation process are done for purpose uses, where Kavitha and Sujatha 2015 have done an evaluation process of soil fertility status in different agro ecosystems in India, where macro and micro nutrients levels were measured to be evaluated in those different ecosystems where they found significant differences in levels of macro and micro nutrients.

The main objective of land evaluation is to forecast the ingrained capability of a land unit to hold up a specific land use for a long period of time without deterioration (Eze 2014). Uses of lands can be done when the suitability of land is available, besides the spatial data that is needed for the agricultural development of land resources potentials (Suryana et al 2005).

Kumar and Somashekar 2014 studied the spatial distribution of macronutrients in some river basin soils in India, where they found that there was not much variation in soil fertility status developed on different landforms in the area, but they found some differences in organic carbon content in soil from $0.05-1.5 \%$. Understanding spatial distributions of macro nutrients and impact factors can be helpful to practice some specific magnitude to modify the availability of macronutrients for soil ecosystem management, thus $\mathrm{Qu}$ et al 2014 found that the availability of macronutrients is controlled by multiple factors, and they are spatially varied.

Verma et al 2005 collected surface samples to analyze the spatial distribution of macronutrients in soils of arid tract of Punjab, India and they revealed that there is a wide variation in soil fertility status of soils developed on various landforms, also they were low in N, P content, and medium to high content of $\mathrm{K}$.

Sokouti and Mahdian 2011 studied the spatial variability of macronutrients for soil fertilization management in Urmia plain, Iran, where they used the geospatial techniques in GIS system to evaluate that. Krigging method using Gaussian semi variogram was found to be precise in estimating and interpolating nutrients rates in soil. Also Wang et al 2009 used the geostatistics and geographic information systems to study some nutrients affected by some factors and their spatial variability $\mathrm{n}$ cropland in China, where they found that the experimental variogram of the log-transformed data of soil organic matter, total nitrogen and extractable 


\section{International Journal of Science and Research (IJSR) \\ ISSN (Online): 2319-7064 \\ Index Copernicus Value (2015): 78.96 | Impact Factor (2015): 6.391}

phosphorus was fitted with an exponential model, while soil extractable potassium was fitted to a spherical model.

Sharma et al. 2010 investigated the profile distribution of total extractable micronutrients $(\mathrm{Zn}, \mathrm{Mn}, \mathrm{Cu}$, and $\mathrm{Fe})$ in soil developed on six physiographic units of semiarid area in India where none of the micronutrients exhibited any consistent pattern of distribution with depth on different geomorphic surfaces, besides Contents of all micronutrients and their forms were higher in fine-textured and uneroded soils than in coarse-textured eroded soils where soil texture is mainly affected by slope and physiographic position. The study of Bulta et al 2016 showed that the means of all micronutrients except Boron showed significant differences among Damboya, KedidaGamela and KechaBira Districts, KambataTambaro zone, Southern Ethiopia and showed moderate spatial dependences, and the range of semivariogram for all studied micronutrients was greater than the average sampling distance indicating that it was adequate enough to catch spatial variability of them.

The main objectives of this study is to Measure soil content of macro and micro nutrients important for plant growth, and
Mapping them spatially, besides testing the relationship between land evaluation classes and spatial distribution of measured nutrients. Where questions of this study were aimed to be answered as is there a relationship between nutrients content in soil and their land evaluation classes? And can one or a combination of these nutrients control land evaluation classes? And changing the class to a different one?

\section{Materials and Methods}

Sampling logistics:

Area of study was selected because it represents an undulating landscape where soils positioned on different settings of landforms. The reason is to study the effect of elevation, slope and some other topographical features on the distribution of soil elemental contents.

The area of study was covering $10,000 \mathrm{Km}^{2}$, samples were selected depending on topographical features of the area where diverse topography been put in the consideration of sampling location.

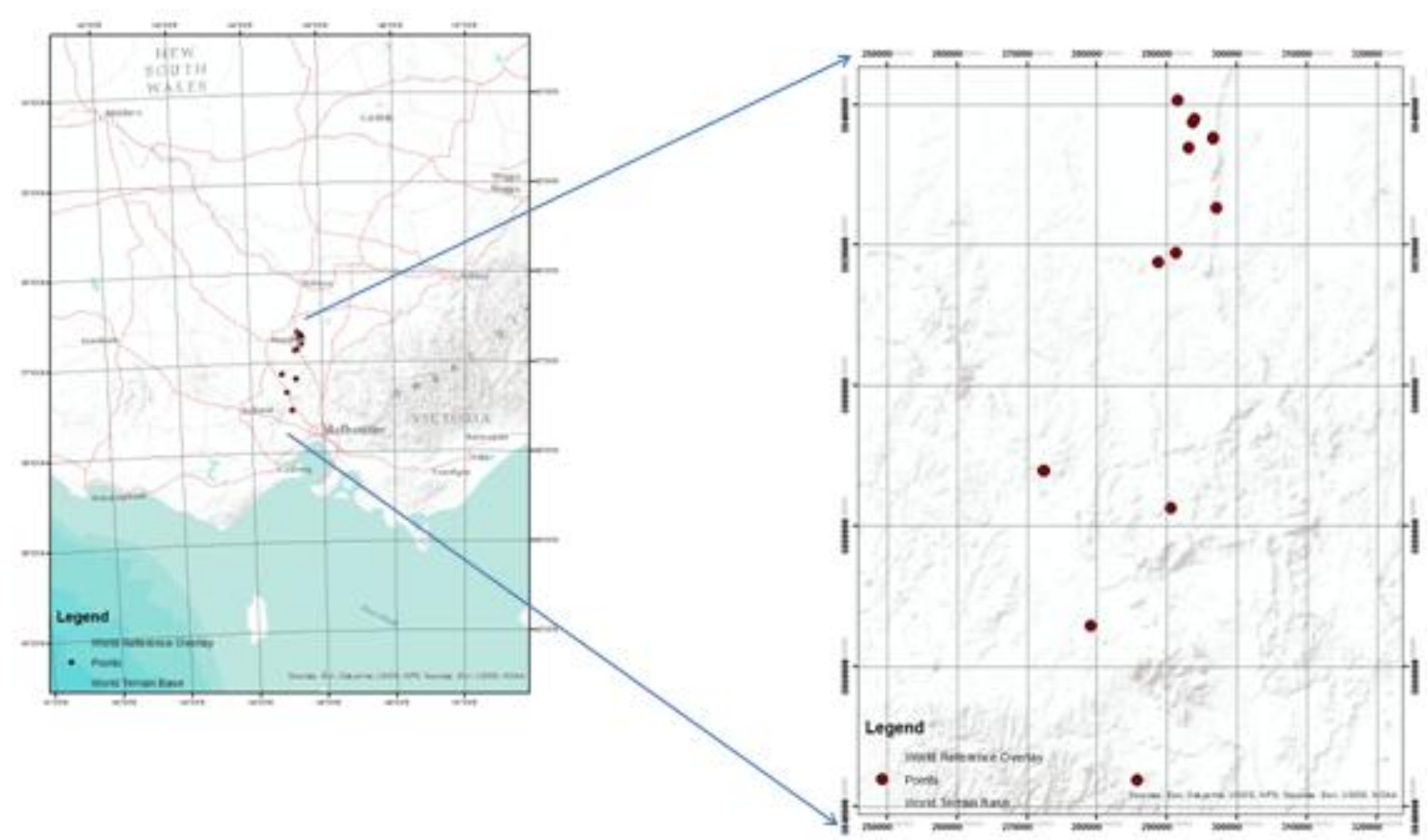

Figure 1: Area of study and samples location

\section{Measurements: \\ Soil properties:}

Physical properties: Soil Texture, Clay, Silt, Sand, P.W were measured due to Black 1965

Chemical properties: PH, EC, ESP, HCO3, CO3, O.C, O.M, Gypsum, CaCO3, CEC meq/100g soil were measured due to Richards 1954.

Macro/Micronutrients analysis: available nitrogen $\mathrm{N}$, carbon $\mathrm{C}$, phosphorous $\mathrm{P}$, potassium $\mathrm{K}$, calcium $\mathrm{Ca}$, magnesium $\mathrm{Mg}$, sodium $\mathrm{Na}$, manganese $\mathrm{Mn}$, iron $\mathrm{Fe}$, sulfur $\mathrm{S}$, copper
$\mathrm{Cu}$, barium $\mathrm{B}$, aluminum $\mathrm{AL}$ were measured in soil samples due to Johansson et al 1996

\section{Topographical features:}

A DEM was created from LiDAR data collected for the area of study of resolution of 25 by 25 meters of a pyramids level: 6, resampling: Nearest Neighbor. And cell size of : 0.00027777778, 0.00027777778. andGCS D_WGS_1984. Topographical features extracted from this DEM were: elevation in meter, slope, flow direction, and flow accumulation due to protocols of ArcGIS 10.3 (ESRI, 2013). Table 3 shows the topographical features of sample locations. 
International Journal of Science and Research (IJSR)

ISSN (Online): 2319-7064

Index Copernicus Value (2015): 78.96 | Impact Factor (2015): 6.391

Table 1 shows the Topographical features extracted from this DEM

\begin{tabular}{|c|c|c|c|c|c|c|}
\hline Pedon no & east & north & elevation & slope & flow direction & flow accumulation \\
\hline 1 & 290581.2 & 5882530 & 672.555 & 89.986 & 16.000 & 4.835 \\
\hline 2 & 297054.4 & 5925232 & 193.715 & 89.962 & 1.000 & 96.769 \\
\hline 3 & 296598.8 & 5935145 & 275.558 & 89.986 & 16.000 & 6.192 \\
\hline 4 & 296591.1 & 5935199 & 273.151 & 89.987 & 16.000 & 5.713 \\
\hline 5 & 293732.7 & 5937433 & 186.959 & 89.951 & 16.000 & 16.808 \\
\hline 6 & 293892.8 & 5937851 & 189.077 & 89.953 & 32.000 & 13.686 \\
\hline 7 & 291588.4 & 5940506 & 167.122 & 89.770 & 32.000 & 123.641 \\
\hline 8 & 293072.1 & 5933810 & 188.639 & 89.900 & 64.000 & 20.673 \\
\hline 9 & 291319.1 & 5918773 & 249.867 & 89.968 & 64.000 & 19.966 \\
\hline 10 & 288799.3 & 5917478 & 226.695 & 89.983 & 8.000 & 10.153 \\
\hline 11 & 272451.4 & 5887843 & 406.539 & 89.980 & 34.834 & 1363.864 \\
\hline 12 & 272393.7 & 5887796 & 405.156 & 89.979 & 64.000 & 295.435 \\
\hline 13 & 290059.2 & 5918126 & 238.281 & 89.976 & 36.000 & 15.059 \\
\hline 14 & 272422.6 & 5887819 & 405.847 & 89.980 & 49.417 & 829.650 \\
\hline
\end{tabular}

\section{Results and Discussion}

\section{Soil Properties}

Table 2 shows soil properties of the studied samples, and they show that sand was a major component of the particle size distribution, and that could be related to the glacial parent materials that these soils were derived from. Beside locations was featured with amounts of rocks and cobbles in soil profile, where soil texture was ranged from loamy sand to sandy clay loam.

Clay content was not as high as other separates, and that influenced the values of CEC where they were low consistently.

$\mathrm{pH}$ values were widely varied, it ranged from slightly acid (6.37) to strongly alkali soils (8.98) and that affected the content of the available macro and micro nutrients in soil (see table 3). Soils with dropped $\mathrm{pH}$ showed lower content of lime due to the acidic soil condition that inhibit accumulation of lime in soil, it was also noticed that the lower $\mathrm{pH}$ value, the higher organic matter in soil, where organic matter content could be a controller to $\mathrm{pH}$ values due to the acidic compounds of the organic matter where it ranged from 12.5-61.5 gm.kg-1 soil.

Lime content ranged from $0.64-72$ gm.kg-1 soil. It showed a wide variation within landscape. Lime content was also related to $\mathrm{pH}$ values and organic matter content where the lower values of lime showed higher $\mathrm{pH}$ values and content of organic matter. Gypsum did not show any significant content in soil due to the high amounts of precipitation received in these soils the matter that leached this compound in soil.

Table 2: Measured soil properties of the studied area

\begin{tabular}{|c|c|c|c|c|c|c|c|c|c|c|c|c|}
\hline ID & & & $\%$ & & & $\mathrm{dS} / \mathrm{m}$ & $\%$ & $\mathrm{gm} \cdot \mathrm{kg}^{-1}$ & $\mathrm{gm} \cdot \mathrm{kg}^{-1}$ & gm. $\mathrm{kg}^{-1}$ & gm. $\mathrm{kg}^{-1}$ & Cmolec/100gm soil \\
\hline & Texture & Clay & Silt & Sand & $\mathrm{PH}$ & $\mathrm{EC}$ & ESP & O.C & O.M & Gyps-um & $\mathrm{CaCO} 3$ & CEC \\
\hline 1 & LS & 8.3 & 5.55 & 86.15 & 7.06 & 21.6 & 6.809 & 0.86 & 1.5 & 0 & 17 & 10.7 \\
\hline 2 & SL & 13.84 & 5.54 & 80.62 & 7.15 & 10.7 & 16.881 & 8.342 & 4.85 & 0 & 4.14 & 11.7 \\
\hline 3 & SCL & 30.86 & 7.42 & 61.72 & 7.35 & 17 & 25.293 & 3.87 & 1.25 & 0 & 72 & 13.37 \\
\hline 4 & LS & 5.67 & 11.37 & 82.96 & 7.16 & 21.5 & 19.088 & 4.128 & 2.4 & 0.001 & 49 & 15.51 \\
\hline 5 & SL & 10.94 & 20 & 69.06 & 6.98 & 22.8 & 12.705 & 4.558 & 2.65 & 0.001 & 0.64 & 9.63 \\
\hline 6 & $\mathrm{~L}$ & 36.9 & 22.71 & 40.39 & 8.98 & 34.5 & 20.291 & 6.278 & 3.65 & 0 & 17.1 & 11.77 \\
\hline 7 & SL & 18.87 & 14.44 & 66.69 & 7.14 & 95.9 & 6.725 & 6.45 & 3.75 & 0 & 24.8 & 11.23 \\
\hline 8 & SCL & 20.17 & 28.83 & 51 & 6.98 & 35.4 & 13.625 & 4.816 & 2.8 & 0 & 22.1 & 14.44 \\
\hline 9 & LS & 8.43 & 19.69 & 71.88 & 6.85 & 18.4 & 4.339 & 5.16 & 3.0 & 0 & 40.4 & 10.16 \\
\hline 10 & SCL & 22.06 & 22.08 & 55.86 & 8.26 & 17 & 2.593 & 13.158 & 7.65 & 0 & 4.07 & 9.09 \\
\hline 11 & CL & 32.26 & 29.35 & 38.39 & 7.26 & 10 & 4.467 & 2.666 & 1.55 & 0 & 18.5 & 10.7 \\
\hline 12 & SCL & 28.76 & 20.49 & 50.75 & 7.42 & 97.2 & 20.23 & 2.58 & 1.5 & 0 & 19.4 & 13.37 \\
\hline 13 & SCL & 24.62 & 19.14 & 56.24 & 6.77 & 82.9 & 7.0736 & 8.686 & 5.05 & 0 & 7.3 & 10.7 \\
\hline 14 & SCL & 13.59 & 20.35 & 66.06 & 6.37 & 24 & 9.746 & 10.578 & 6.15 & 0 & 5.5 & 16.05 \\
\hline
\end{tabular}

\section{Available Macro/Micro Nutrients analysis:}

Available elemental analysis of macro micro nutrients were conducted, availablenitrogen $\mathrm{N}$, carbon $\mathrm{C}$, phosphorous $\mathrm{P}$, potassium $\mathrm{K}$, calcium $\mathrm{Ca}$, magnesium $\mathrm{Mg}$, sodium $\mathrm{Na}$, manganese $\mathrm{Mn}$, iron $\mathrm{Fe}$, sulfur $\mathrm{S}$, copper $\mathrm{Cu}$, barium $\mathrm{B}$, aluminum AL were measured. Table 3 showed the available elements in soil samples. Table 3 shows that the content of nitrogen was low because these soils are virgin and not used for cropping system, the reason when compare to soils used in cropping, it reflects low levels of nitrogen content. The possible losses of that element could be related to leaching as nitrate more of volatilization as ammonium due to the high amount of received precipitation (Valiela and Teal 1979). Phosphorous content was higher than what is expected in soils without fertilization (virgin soils) and that also could be related to $\mathrm{pH}$ ranges of soils. Phosphorus was directly affected,where in alkaline $\mathrm{pH}$ values, greater than pH 7.5 for example, phosphate ions tended to react with calcium and magnesium to form less soluble compounds (Grant et al 2001).

\section{Volume 6 Issue 7, July 2017 www.ijsr.net}




\section{International Journal of Science and Research (IJSR) \\ ISSN (Online): 2319-7064 \\ Index Copernicus Value (2015): 78.96 | Impact Factor (2015): 6.391}

Potassium, and Sulfer are major plant nutrients that appear to be less affected directly by soil $\mathrm{pH}$ than many others, but still are to some extent, they were showing a relative high contents in some sites, where potassium contents varied from $0-34 \mathrm{mg} / \mathrm{l}$, and sulfer was higher than what average soil content of that element is where it varied from $1.8-9.9 \mathrm{mg} / \mathrm{l}$. Most of the other nutrients (micronutrients especially) tend to be less available when soil $\mathrm{pH}$ is above 7.5, and in fact are optimally available at a slightly acidic pH, e.g. 6.5 to 6.8 and that what was reflected when we look at the content of $\mathrm{Fe}$ and $\mathrm{Al}$ where they showed high content, because of the mildly acid and neutral $\mathrm{pH}$ soils were(Bohn et al 2002)

Sodium did not show high content as for it was washed out from the exchange complex due to the high amount of precipitation received in this area, but calcium and magnesium content did not show that behavior, where that could be related to the origin of the parent material, and the original content of carbonate compounds in the soil (Jenny 1994).

Table 3: The Macro/Micronutrients analysis of soil samples

\begin{tabular}{|l|l|l|l|l|l|l|l|l|l|l|l|l|l|}
\hline ID & $\mathrm{N}$ & $\mathrm{OC}$ & $\mathrm{P}$ & $\mathrm{K}$ & $\mathrm{Ca}$ & $\mathrm{Mg}$ & $\mathrm{Na}$ & $\mathrm{S}$ & $\mathrm{Mn}$ & $\mathrm{Fe}$ & $\mathrm{Cu}$ & $\mathrm{B}$ & $\mathrm{AL}$ \\
\hline 1 & 0.2 & 2.6 & 0.9 & 1.2 & 71.4 & 24.7 & 0.6 & 9.5 & 8.2 & 50.7 & 0.2 & 0.1 & 63.7 \\
\hline 2 & 0.2 & 2.2 & 0.2 & 0 & 176.2 & 64.3 & 0.6 & 9.4 & 22.6 & 15.8 & 0.4 & 0.02 & 92.5 \\
\hline 3 & 0.32 & 3.4 & 2.1 & 1.8 & 251.4 & 103.6 & 1.6 & 9.8 & 31.2 & 16.2 & 0.8 & 0.05 & 86.5 \\
\hline 4 & 0.35 & 3.7 & 0.8 & 0 & 193.8 & 96.5 & 0.6 & 9.4 & 27.9 & 8.9 & 0.6 & 0.1 & 70.3 \\
\hline 5 & 0.18 & 2.3 & 1.7 & 12.9 & 117.3 & 31.3 & 0.4 & 9.7 & 4.4 & 45.4 & 0.2 & 0.04 & 47.9 \\
\hline 6 & 0.22 & 2.6 & 2.5 & 9.7 & 197 & 37.2 & 0.4 & 9.9 & 23.8 & 19.4 & 0.2 & 0.1 & 57.3 \\
\hline 7 & 0.16 & 2.0 & 0.9 & 8.8 & 62.9 & 30 & 0.4 & 9.6 & 22.9 & 16.6 & 0.2 & 0.0 & 54.4 \\
\hline 8 & 0.27 & 3.0 & 2 & 34 & 102.6 & 56 & 1.4 & 9.8 & 8.7 & 31 & 0.2 & 0.0 & 62.2 \\
\hline 9 & 0.2 & 2.2 & 4.7 & 6.4 & 40.2 & 15.3 & 0.4 & 9.2 & 5.2 & 58.8 & 0.2 & 0.01 & 35.6 \\
\hline 10 & 0.19 & 2.0 & 0.7 & 5.1 & 24.7 & 16.7 & 0.4 & 9.1 & 6.5 & 25.4 & 0.1 & 0.05 & 39.4 \\
\hline 11 & 0.37 & 4.2 & 1.4 & 8.2 & 41 & 19 & 0.4 & 9.3 & 11.7 & 16.4 & 0.1 & 0.05 & 89.5 \\
\hline 12 & 0.36 & 4.0 & 0.9 & 3.5 & 21.2 & 12.9 & 0.4 & 9.5 & 3.7 & 31.6 & 0.1 & 0.1 & 41.8 \\
\hline 13 & 0.08 & 1.0 & 1.8 & 5.8 & 95 & 73 & 0.4 & 1.8 & 15.4 & 29.1 & 1 & 0.05 & 51.8 \\
\hline 14 & 1.1 & 5.5 & 0.1 & 9.3 & 98.2 & 149.6 & 0.4 & 9.4 & 10.9 & 21.3 & 0.4 & 0.05 & 47.3 \\
\hline
\end{tabular}

\section{Spatial distribution of macro/micro elements:}

Macro and micro nutrients, Nitrogen, and organic carbon were geospatially plotted using Inverse Distance Weighting
(IDW) deterministic method (ESRI 2013). Figure 2(a-l) shows the spatial distribution of macro and micro elements in the studied area
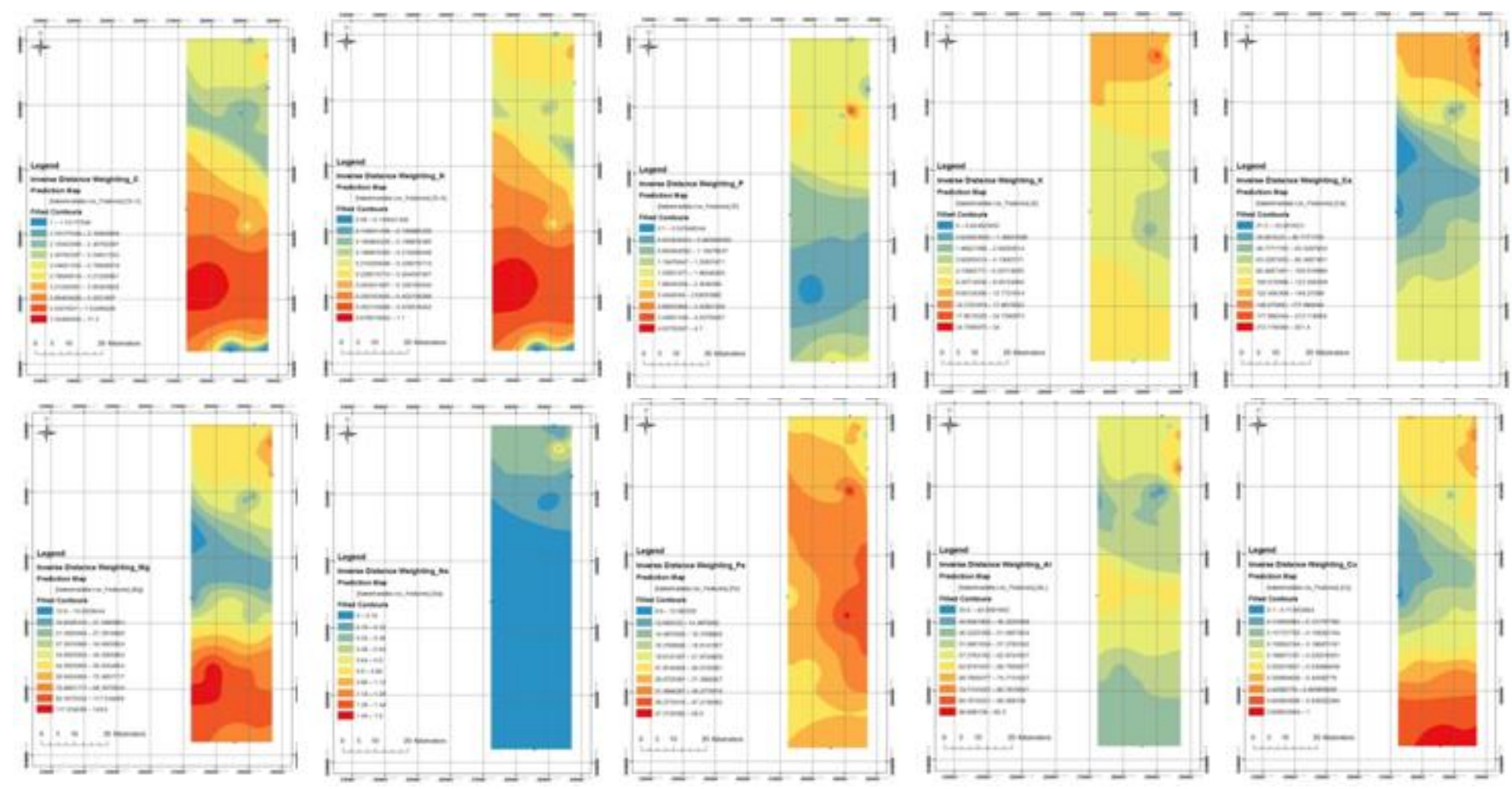

\section{Volume 6 Issue 7, July 2017 www.ijsr.net}


International Journal of Science and Research (IJSR)

ISSN (Online): 2319-7064

Index Copernicus Value (2015): 78.96 | Impact Factor (2015): 6.391
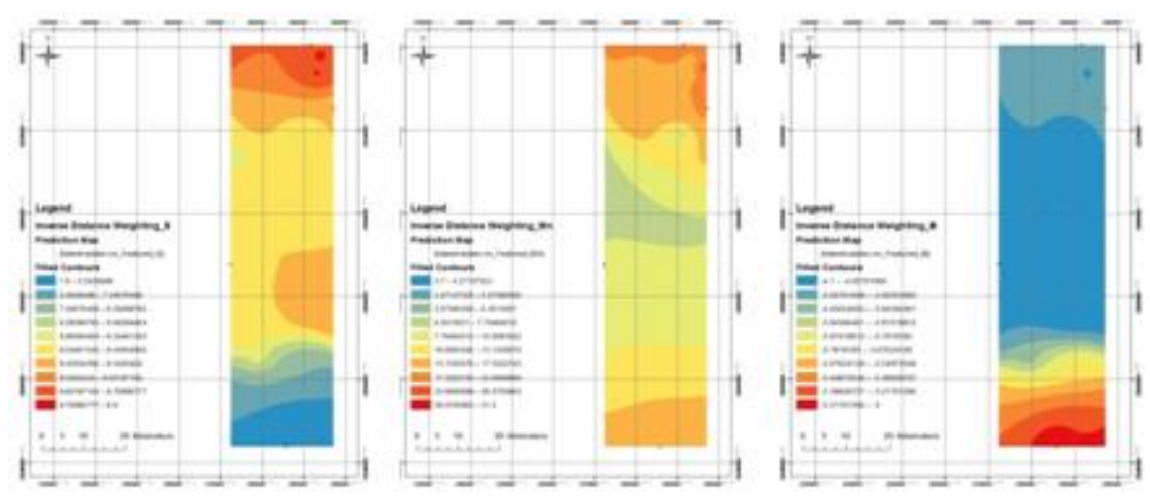

Figure 2: Spatial distribution of macro and micro nutrients

The overall variability that could be noticed from figure 2 , is that elements were varied differently, some of them showed similarity in variability the matter that we can divide them into categories, ten classes were selected in the procedure of IDW used for mapping contents and variability of the area of study soils but these categories differed in how they plotted spatially.

A cluster analysis results showed thatdendogram tree of group variables of micro/macro elements content in soil (figure 3).Four groups were clustered. The first group included $\mathrm{N}, \mathrm{Cu}, \mathrm{Na}, \mathrm{P}, \mathrm{C}, \mathrm{B}, \mathrm{S}, \mathrm{K}$, and $\mathrm{Mn}$, and the second group was $\mathrm{Fe}, \mathrm{Mn}, \mathrm{K}$, and $\mathrm{S}$. $\mathrm{Mg}$ and $\mathrm{Al}$ were classified together and $\mathrm{Ca}$ was a whole one group.

Although the $\mathrm{N}$ and $\mathrm{C}$ showed same variability so far, and that could be related to the $\mathrm{C} / \mathrm{N}$ ratio of soils where they were mostly homogenous, besides the same climate conditions of the area of study (add reference confirming such result). Also, some other elements were included in this group and that could be related to low content of these elements in soil the matter they were clustered together.

The other group of micro/macro elements included Fe, Mn, and $\mathrm{K}$ and these elements were showing closer concentrations in soil, the matter they were clustered together, also clustering could be a result of the fact of availability of these elements as they were discussed in previous paragraph.

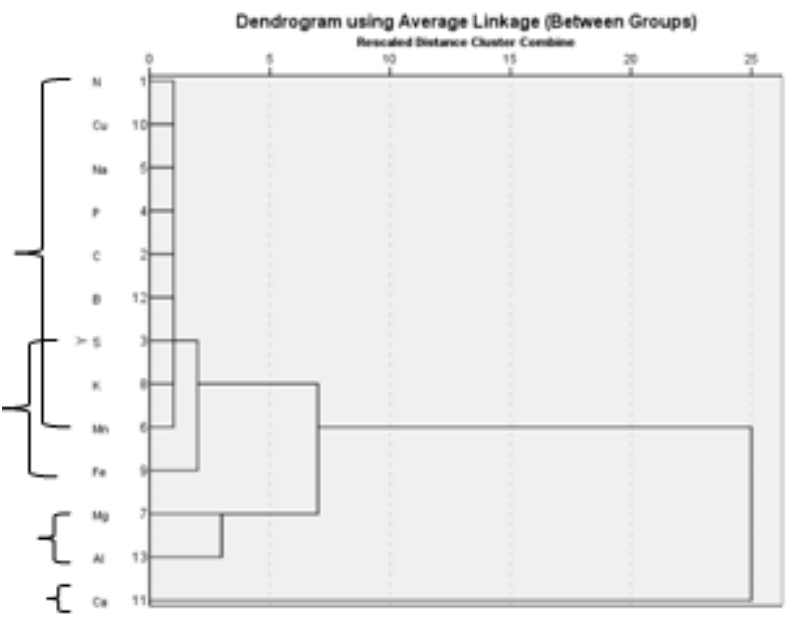

Figure 3: Dendogram tree of element grouping in clusters

Land Evaluation and suitability for crop production:

Table 3 shows the suitability class of each pedon for crop production for different grain crops where the limitation factor was the slope only where soils were not showing other limitations such as salinity because the area of study is receiving quite good quantities of precipitation the matter that leach salts from soil, therefore classes were determined due to slope factor as shown in table 3 .

Most of suitability classes were N1 class because of the main topography of the area of study is being undulating bushlands that makes the slope the main limiting factor. Also there was matching in suitability classes for wheat and barley grain crop in all points of study, and that is related to the fact that limitation factor is affecting these crops the same (figure 4).

Pedons 7-10 showed different classes of suitability because they are geographically lay in less undulating areas of the whole bushland valley, the matter that enhanced class N1 to S2 and S1.

The dominant class that shown in the area of study was N1 followed by S2, S3, and S1. Class N1 does not show good suitability for grain crops production where this class is suitable for other purposes other than farming (sys 1980) while class 2 is mildly good for crop production and $\mathrm{S} 1$ is super suitable while S3 shows more slope limitations where it was more undulating and steep than the other classes. Therefore

Table 4: Land Classes due Slope as a Limiting Factor

\begin{tabular}{|c|c|c|c|}
\hline Crop & Wheat & Barley & Rice \\
\hline Limitation & \multicolumn{3}{|c|}{ Slope } \\
\hline Pedon no. & & & \\
\hline P1 & N1 & N1 & N1 \\
\hline P2 & N1 & N1 & N1 \\
\hline P3 & N1 & N1 & N1 \\
\hline P4 & N1 & N1 & N1 \\
\hline P5 & N1 & N1 & S2 \\
\hline P6 & N1 & N1 & S3 \\
\hline P7 & S2 & S2 & S2 \\
\hline P8 & S1 & S1 & S2 \\
\hline P9 & S2 & S2 & S2 \\
\hline P10 & S2 & S2 & S2 \\
\hline P11 & S1 & S1 & S3 \\
\hline P12 & N1 & N1 & N1 \\
\hline P13 & N1 & N1 & N1 \\
\hline P14 & N1 & N1 & N1 \\
\hline
\end{tabular}

Inverse distance weighting method under geostatistical analysis was used to interpolate the prediction map of land suitability classes. Figure (4) shows the prediction map of 


\section{International Journal of Science and Research (IJSR) \\ ISSN (Online): 2319-7064 \\ Index Copernicus Value (2015): 78.96 | Impact Factor (2015): 6.391}

land classes for wheat, barley, and rice crops. It is very clear that wheat and barley have the same land classes while rice was different, and the reason could be related to the fact that wheat and barley are share the same impact for some limitation other than slope such as salinity, soil depth etc., the matter that led to have the same spatial distribution of classes. Moreover, rice is more affected by slope because slope is affecting the movement and quantity of water for plant rotation, therefore different classes were shown in this prediction map.
It is important to mention that major land class was not suitable for cropping $(\mathrm{N})$ could be related to the fact the way land class was evaluated through, where the multiplication method suggested by Sys 1980 is always going low in values because of the multiplication processes where the more small fractions multiplications, the smaller value will be resulted, that leads to low values eventually, then land class will be also low.
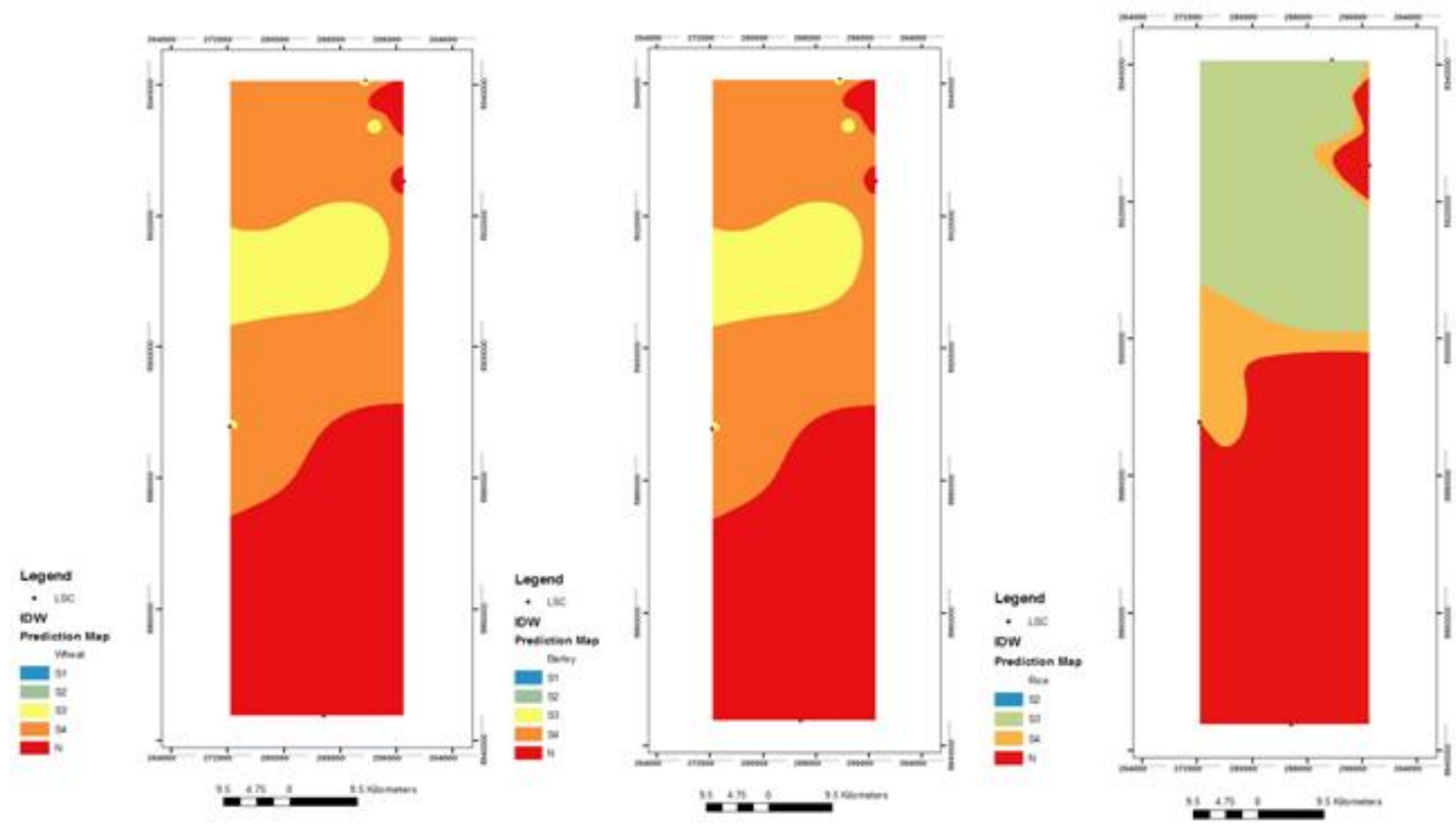

Figure 4: Land Suitability Classes for Wheat, Barley, and rice crops

\section{References}

[1] AbdelRahman, M.A., Natarajan, A. and Hegde, R., 2016. Assessment of land suitability and capability by integrating remote sensing and GIS for agriculture in Chamarajanagar district, Karnataka, India. The Egyptian Journal of Remote Sensing and Space Science, 19(1), pp.125-141.

[2] Black, C.A., 1965. Methods Of Soil Analysis Part1And2. American Society Of Agronomy, Inc.; USA.

[3] Bohn, H.L., Myer, R.A. and O'Connor, G.A., 2002. Soil chemistry.John Wiley \& Sons.

[4] Bulta, A.L., Assefa, T.M., Woldeyohannes, W.H. and Desta, H.S., 2016. Soil micronutrients status assessment, mapping and spatial distribution of Damboya, KedidaGamela and KechaBira Districts, KambataTambaro zone, Southern Ethiopia. African Journal of Agricultural Research, 11(44), pp.4504-4516.

[5] ESRI ArcGIS Help 10.1, 2013. Fundamentals of panchromatic sharpening. Available from: http://resources.arcgis.com/en/help/main/10.1/ind ex.html\#//009t000000mw000000

[6] Eze, H.O., 2014. Assessment of the Relationship Between Environmental Quality and Residential Housing Rents In Enugu Metropolis, Nigeria (Doctoral dissertation).
[7] FAO 1979 report of the second meeting of the working group on soil degradation assessment methodology. Rome, FAO

[8] FAO: 1984, Land, Food and People, Rome, FAO.

[9] Grant, C.A., Flaten, D.N., Tomasiewicz, D.J. and Sheppard, S.C., 2001.The importance of early season phosphorus nutrition. Canadian Journal of Plant Science, 81(2), pp.211-224.

[10] Jenny, H., 1994. Factors of soil formation: a system of quantitative pedology. Courier Corporation.

[11] Kavitha, C. and Sujatha, M.P., 2015. Evaluation of soil fertility status in various agro ecosystems of Thrissur District, Kerala, India. International Journal of Agriculture and Crop Sciences, 8(3), p.328.

[12] Kumar, P.S., Elango, L. and James, E.J., 2014.Assessment of hydrochemistry and groundwater quality in the coastal area of South Chennai, India. Arabian Journal of Geosciences, 7(7), pp.26412653.

[13] Oldeman, L.R., Hakkeling, R.T.A. and Sombroek, W.G., 1991. World map of the status of human-induced soil degradation: an explanatory note, 2 nd. rev (p. 34). ISRIC [etc.].

[14] Qu, M., Li, W. and Zhang, C., 2014.County-scale spatial variability of macronutrient availability ratios in paddy soils. Applied and Environmental Soil Science, 2014.

\section{Volume 6 Issue 7, July 2017 www.ijsr.net}




\section{International Journal of Science and Research (IJSR) \\ ISSN (Online): 2319-7064}

Index Copernicus Value (2015): 78.96 | Impact Factor (2015): 6.391

[15] Richards, L.A., Diagnosis and improvement of saline and alkali soils. Washington: United States Salinity Laboratory, 1954. 160p. USDA. Agriculture Handbook, 60.

[16] Sharma, B.D., Arora, H., Kumar, R. and Nayyar, V.K., 2004. Relationships between soil characteristics and total and DTPA-extractable micronutrients in Inceptisols of Punjab. Communications in soil science and plant analysis, 35(5-6), pp.799-818.

[17] Sokouti, R. and Mahdian, M.H., 2011. Spatial variability of macronutrient for soil fertilization management: A case study on Urmia plain. International Journal of Soil Science, 6(1), p.49.

[18] Sys, C., 1980. PapT 3 LAND CHARACTERISTICS AND QUALITIES AND METHODS OP RATING THEM. Land Evaluation Guidelines for Rainfed Agriculture: Report, 52, p.23.

[19] Valiela, I. and Teal, J.M., 1979. The nitrogen budget of a salt marsh ecosystem. Nature, 280(5724), pp.652-656.

[20] Verma, V.K., Patel, L.B., Toor, G.S. and Sharma, P.K., 2005. Spatial distribution of macronutrients in soils of arid tract of Punjab, India. International Journal of Agriculture \& Biology, 7(2), pp.370-372.

[21] Wang, Z.M., Song, K.S., Zhang, B., Liu, D.W., Li, X.Y., Ren, C.Y., Zhang, S.M., Luo, L. and Zhang, C.H., 2009. Spatial variability and affecting factors of soil nutrients in croplands of Northeast China: a case study in Dehui County. Plant soil environ, 55(3), p.110Y120.

[22]Zonneveld, I. S.: 1983, 'Principles of bioindication', Environ. Monit. Assess. 3, 207-217.

Volume 6 Issue 7, July 2017 www.ijsr.net 